\title{
An Investigation on Factors affecting Exchange Rate Fluctuations in Sri Lanka
}

\author{
S.H.I Rajakaruna
}

\begin{abstract}
This article examines the factors that affect exchange rate fluctuations in Sri Lanka. It attempts to identify how the changes in inflation, interest rates, terms of trade, Net Foreign Purchases (a proxy for Net Capital Inflows), official intervention and remittances affect the fluctuations in Sri Lanka's exchange rate. There are two specific objectives, which are identifying the relationship between the factors and the exchange rate fluctuations, and investigating the impact of the factors on the exchange rate. The Multiple Regression Model has been used to analyse the results, with monthly data, for the period 2001 to 2010. The Vector Auto Regression Model has been used an alternative specification to this model. Results obtained by the Multiple Regression model suggest that net official intervention is the most effective and significant determinant of the exchange rate during the sample period. Inflation and net foreign purchases (as a proxy for Net Capital Inflows) are reduced to be less effective and non-significant determinants of the exchange rate. However, it can be seen that there is a direct link between the two determinants of net official intervention and net foreign purchases. A negative relationship exists between the exchange rate and inflation, interest rate, remittances, and terms of trade, whereas a positive relationship exists between the exchange rate and net foreign purchases. According to the estimation results of the Vector Auto Regression model, net official intervention, net foreign purchases and call money rate cause the most fluctuations in the exchange rate.
\end{abstract}




\section{Introduction}

The exchange rate of a country's currency is the value of its money for international trade in goods, services and finance. Therefore, it is part and parcel of the monetary condition of a country. Hence, the central banks, being the monetary authorities, have been given discretionary powers under the relevant statutes to manage the exchange rate as part of its monetary, financial and economic development policies. From a macroeconomic perspective, exchange rate policy is instrumental in the mobilization of foreign savings and capital, to fill the domestic resource gap and expand investments. Various public views are often expressed as to how the central banks should manage the exchange rate and what factors should be taken into consideration.

The changes in exchange rates will have both favorable and unfavorable impacts on economic activities and living standard of the public because of the largely globalized trade and finance involving the exchange of currencies. In general, appreciation of a country's currency will have the following effects, whereas depreciation will have the opposite effects:

- Lowering the domestic prices of imports because the cost of imports in the domestic currency will be less due to the higher value of the domestic currency. As a result, inflation will be lower, depending on the extent of the imports in domestic consumption and production activities.

- The Country's outstanding foreign debt equivalent of domestic currency will be lower and, therefore, the burden on foreign debt repayment will be less.

- One unfavorable effect will be that the lower import prices will encourage imports and worsen the country's trade balance (net position between exports and imports).

- Another unfavorable effect will be that exporters will be discouraged by the reduction in their income in domestic currency, which will adversely affect the export industries. However, if domestic inflation will be lower due to reduced import prices, there will be higher foreign demand for exports, which will off-set the initial reduction in exporters' income.

As described below in the Literature Review, about ninety per cent of the studies (both internationally and locally) have used the following factors on exchange rate determinants, differentials in inflation, differentials in interest rate, current account deficit, public debt, terms of trade, political stability and economic performance and stock market. In many of the Sri Lankan studies mentioned, they have examined a particular issue. In other words, they have done a partial study of the exchange rate determinants. 
Hence this paper attempts to fulfil that research gap and conducts a comprehensive study for the period 2001-2010 using interest rates, terms of trade, and capital inflows as the key exchange rate determinants in order to understand the relationship of these variables with the exchange rate. Especially, this paper examines the impact of capital inflows on the exchange rate, as the capital account was substantially liberalized during the year 2010 .

The proposed empirical study will be deductive in nature, where well recognized theories will be tested using empirical data relating to Sri Lanka (2001-2010). Secondary data which are available at the Central Bank of Sri Lanka and IMF will be used for the empirical analysis. I intend to use different estimation methods to obtain outcomes such as Unit-root test, lag selection criteria, Impulse Response and Variance decomposition test, Vector Auto Regression and OLS method.

The study attempts to suggest a suitable regression line to determine the relationship between the factors and the exchange rate.

\section{(i.e. Exchange Rate $=\beta_{0}+\beta_{1}$ Interest Rate $+\beta 2$ Inflation $+\beta 3$ Balance of Trade + $\beta 4$ net foreign purchases $+\beta 5$ official intervention $+\beta 6$ remittances $+U$ )}

The remainder of the paper is organized as follows. In Section 2, the literature on exchange rate determinants will be reviewed. In Section 3, the exchange rate policy in Sri Lanka will be described. In Section 4, the theoretical foundation relating to the study will be examined. The next section deals with the analytical framework, namely, the econometric models used for assessing the determinants of the exchange rate in Sri Lanka. The data employed to estimate these models will also be discussed in this section. Section 6 presents the preview of the data and Section 7 explains the findings in comparison with the findings of other researchers, who have studied the determinants of exchange rate in other countries. The final Section presents the conclusions of the study, limitations as well as recommendations for future research.

\section{Literature Survey}

Simone and Razzak (1999) have examined some unsettled theoretical and empirical issues regarding the relationship between nominal exchange rates and interest rate differentials and provide a model for the behavior of exchange rate in the long run, where interest rates are determined in the bond market. The model predicts that an increase in the differential appreciates the home currency. They have tested the model for the U. S. Dollar against the Deutsche Mark, the British pound, the Japanese yen, and the Canadian dollar. The first two pairs of exchange rates- for which purchasing power parity seems to hold- display a strong relationship with interest rate differentials. 
In contrast to the preponderance of developed country studies of the behavior of exchange rates, evidence on the behavior of developing country exchange rates is scarce. Those studies which have examined the determinants of developing country exchange rates have largely focused on Latin America, and have emphasized the role of movements in terms of trade in driving exchange rate movements (see Diaz-Alejandro (1982), and Edwards (1989)). There is also extensive literature for some developed countries that links exogenous movements in terms of trade of commodity-exporting countries and changes in their exchange rates, particularly for commodity exporters in Canada and Australia (see Amano and van Norden (1995) and Gruen and Wilkinson (1994)).

The size of net foreign assets is likely to be associated with a more appreciated exchange rate in the long run. Higher net foreign assets induce larger expenditure on domestic goods, thus raising the price of non-tradables, and appreciating the exchange rate. An alternative mechanism is based on the absence of price equalization of tradables: a country that reaches a higher level of net foreign assets can afford to finance a worse current account balance and can therefore sustain a loss in competitiveness, associated with a more appreciated exchange rate. For a theoretical discussion and empirical evidence, see Lane and Milesi-Ferretti (2000).

Ezirim, and Muoghalu (2006) have used three theories namely, Debt Burden theory, Foreign Direct Investment theory and Contemporary Exchange Rate theory. The methods used in their study are OLS (Ordinary Least Square) Method and EML (Exact Maximum Likelihood) model. The study found clear cut and significant relationships between the three-external sector economic crises. Relatively, foreign investment burden, international oil prices and previous exchange rate conditions are important arguments in explaining current exchange rate crisis in a typical LDC. External debt burden was not found to be a consistent factor contributing to exchange rates crisis in Nigeria. A major imperative of these results is that the observed role of the investment burden was that of putting immense pressures on the exchange rates, and thus aggravating the crisis condition. External debt burden does not have the same magnitude of effect.

Wimalasuriya (2007) has used PPP as the theoretical basis to examine exchange rate passthrough into domestic prices in Sri Lanka. The relevance of the study lies on the fact that domestic price changes due to changes in the exchange rate could be significant in monetary policy decision making. Pass-through is estimated taking two approaches. First, pass-through into import prices is estimated with the use of a Log-Linear Regression Model. The results obtained suggest that exchange rate pass-through into import prices is around fifty per cent, that is, import prices increase by about 0.5 per cent as a result of a 1 per cent depreciation of the Nominal Effective Exchange Rate. Second, taking a Vector Autoregressive approach, exchange rate pass-through into a set of prices in the "pricing chain" is estimated. Namely, exchange rate pass-through to factors input prices, trade prices, wholesale producer prices and 
retail consumer prices are examined, with the presumption that changes in the exchange rate are due to shocks exogenous to the model. The results obtained for this model suggest that exchange rate pass-through into consumer prices is about thirty per cent, although passthrough into wholesale producer prices was found to be complete. The findings from the second model further suggest that changes in the exchange rate could have significant implications for the trade balance.

Alawattage (2005) has examined the effectiveness of the exchange rate policy in Sri Lanka in achieving external competitiveness since the liberalization of the economy in 1977. This paper uses the Marshall- Lerner Theory and the conventional two-country trade model that explains the traditional approach to Balance of Payment (BOP) and was applied using quarterly data covering the period of 1978:1 to 2000:4. Results reveal that the Real Effective Exchange Rate (REER) does not have significant impact on improving the Trade Balance (TB) particularly in the short run, implying a blurred J-Curve phenomenon. Even though the co-integration tests reveal that there is a long run relationship between TB and the REER, it shows a very marginal impact in improving TB in the long run.

From the foregone review, we see that nationally the authors have done partial and comprehensive studies on exchange rates. Partial studies have only used one variable and its effect on the exchange rate. Comprehensive studies were mostly related to exchange rate regimes, using past data. However, internationally, authors have done cross sectional data studies using two countries. Further, when choosing the exchange rate determinants, they have taken into account the macro economic situation of that country. Both national and international studies have not used 'Net Capital Inflows' as a variable due to their capital account not being fully liberalized during the time of their study. This article sets out to contribute to knowledge in this area using simple and convenient procedure that would enable useful and reliable conclusions.

\section{Exchange Rate Policy in Sri Lanka}

Sri Lanka followed the fixed exchange rate system until November 15, 1977. During the period from 1950 to November 15, 1977, the exchange rate for US\$ was revised from Rs. 4.76 to Rs. 8.60. Furthermore, the whole world followed the fixed exchange rate system until early $1970 \mathrm{~s}$ under the Bretton Woods system which was set up by the IMF in 1947. Still, there are many countries that follow the fixed exchange rate system or some variants of it.

During the period from November 16, 1977 to January 22, 2001, Sri Lanka followed the managed floating exchange rate system. US\$ was the foreign currency that the Central Bank engaged in transactions with banks and the band was fixed for the exchange rate for US\$. During this period, the average of buying and selling rates for US $\$$ was gradually revised from 
Rs. 16.00 to Rs. 81.23. Accordingly, the band was increased from Rs. 15.97 (buying rate) and Rs.16.03 (selling rate) to Rs. 77.40 (buying rate) and Rs.85.13 (selling rate). However, due to heavy speculation toward the depreciation of the rupee during the second half of 2000 , the CBSL several times revised the selling rate upward while selling a significant amount of US\$ reserves.

The floating exchange rate system allows the market forces to determine the exchange rate without direct intervention of the central bank, given any prevailing controls on foreign exchange transactions. Accordingly, the exchange rate is free to fluctuate in response to changes in demand and supply factors. Since the central bank does not have to intervene in the foreign exchange market, it can conduct the monetary policy independently from the balance of payments as long as the exchange rate is free to fluctuate, to clear the imbalances in the foreign exchange market. However, if the exchange rate volatility at any time is considered high, the central bank will intervene in the market by buying or selling foreign exchange to maintain greater stability in the exchange rate. Sri Lanka has been following this system since January 23, 2001.

Finally, the CBSL decided to float the currency with effect from January 23, 2001 and discontinued its buying and selling dollars in the open market. According to some economists, the current exchange rate system is a managed float because the central bank intervenes (buy and sell) in the market to maintain the exchange rate without much volatility. However, the managed float system and the central bank's intervention under the floating rate system to reduce any unhealthy volatility, as decided by the central bank in view of the current macroeconomic circumstances, are completely two different systems of exchange rate management.

As Sri Lanka currently follows a flexible exchange rate regime, the exchange rate of the country is determined by the supply and demand for foreign exchange in the economy. The supply of foreign exchange depends on the inflows to the economy such as export proceeds, workers' remittances, tourist earnings, direct investment flows and foreign loans, while the demand for the same depends on outflows such as import payments and loan repayments. In Sri Lanka, foreign exchange earnings have persistently continued at a lower level than the demand for the same. Accordingly, a current account deficit has been a noticeable feature of the Sri Lankan economy.

\section{Theoretical Foundation}

General exchange rate equilibrium models include the Mundell- Fleming model, which deals with the equilibrium of the goods market, money market and balance of payments, but lacks micro-foundations to some extent; the Balassa-Samuelson model, which is built on the 
maximization of firms profit; the Redux model developed by Obestfeld and Rogoff, the PTM (Pricing to Market) model, a simple monetary model with price flexibility created on the maximization of consumer's utility and the Dornbusch model (or Mundell-FlemingDornbusch model). These are actually obtained by combining the monetary equilibrium with the adjustment of price and the adjustment of output toward their long run equilibrium, and can be called hybrids of monetary equilibrium with PPP or UCIRP. The balance of payments is covered in this investigation since many studies regard it as a foundation of equilibrium exchange rate determination.

The basic idea of PPP was initiated by classical economists such as David Ricardo in the $19^{\text {th }}$ century. PPP describes the theory of law of one price for a standard commodity basket applied internationally. According to this theory, the exchange rate between currencies of two countries should be equal to the ratio of price levels of two respective countries.

When the relationship of exchange rate is presented in an equation form, let 'Pr' be the rupee price of the standard commodity basket in Sri Lanka and 'P\$' be the dollar price of the same basket in the United States. PPP states that the exchange rate between their rupee and the dollar should be,

$$
\mathrm{S}=\operatorname{Pr} / \mathrm{P} \$
$$

Where ' $\mathrm{S}$ ' is the rupee value of one dollar. The basic concept is that as a currency, it should be able to buy the same bundle of goods in the home country or abroad. In addition, to give an alternative approach to the PPP, the above - mentioned equation can be presented as follows;

$$
\operatorname{Pr}=\mathrm{S} * \mathrm{P} \$
$$

This equation states that the Dollar price of the commodity basket in Sri Lanka, i.e. 'Pr', must be the same as the Sri Lanka rupee value of the commodity basket in USA. Therefore, PPP states that the price of the standard commodity basket be the same across countries when measured in a common currency.

If the above-mentioned condition is an absolute version of PPP, the relative version or rate of change form can be presented as follows;

$$
\mathrm{e}=\mu \mathrm{r}-\mu \$
$$

Where " $\mathrm{e}$ " is the rate of change in the exchange rate and ' $\mu \mathrm{r}$ ' and ' $\mu \$$ ' are the inflation rates in Sri Lanka and the USA respectively.

It is important to examine the importance of PPP for international trade. The different interest rates to compensate deviations from the PPP are completely eliminated when PPP holds. Further, competitiveness in the world market will not be affected by the changes in the exchange rate when PPP holds. When there are deviations from PPP, changes in the nominal 
exchange rate cause changes in the real exchange rates, affecting the international competitiveness of countries.

The second model, the Mundell-Fleming model, is extended from a closed IS-LM model. Unlike the simple monetary model, in which prices are viewed as flexible, it assumes that prices are preset in the short run. In addition to the internal monetary market equilibrium goods market equilibrium, and external equilibrium condition, the balance of payments is also considered in the Mundell- Fleming model. Thus, it can be viewed as a general equilibrium model. One of the most important forecasts of the model is the so called dilemma, which states that perfect capital mobility, monetary policy independence and a fixed exchange rate regime cannot be achieved simultaneously. In the long run, the exchange rate level is perfectly correlated with the level of monetary supply and monetary policy may only play a trivial role in economic growth. Another important forecast is that devaluation may lead to further devaluation if fiscal discipline, inflation and the balance of payments are not well managed, because a self-fulfilling bubble may be produced. Finally, the impact of devaluation on current account improvement may be weakened if an economy is heavily dependent on the re-export processing industry.

The third monetary model, the Dornbusch model, loosens the condition that prices must be preset, but allows for slow price adjustments. A famous insight into the policy implications of this model is the overshooting of the nominal exchange rate over its long-run equilibrium, when an economic system is shocked with monetary supply. This character is regarded as an advantage of a fixed exchange rate regime over a floating one. This model shows that once a real economic shock happens, markets may move to equilibrium either through a flexible exchange rate or change of prices. The difference between the two is mainly that in the latter, adjustment may consume more time and be less risky than in the former. If prices are relatively flexible and inflation can be controlled in a moderate range, a fixed exchange rate regime is desirable.

These models were criticized frequently for their lack of micro foundations and for their failure to elucidate the effect of the balance of payment on the determination of the exchange rate. However, their clear implications for policymakers should not be underestimated.

\section{Methodology}

\section{The Multiple Regression Model}

I intend to use the Multiple Regression model, which relates to a given dependent variable ' $\mathrm{Y}$ ' to several independent variables, $\mathrm{X} 1, \mathrm{X} 2, \mathrm{X} 3, \ldots \ldots \ldots \mathrm{Xk}$. The multiple regression models have the following general formulation. 


$$
Y=\beta 1 X+\beta 2 X+\beta 3 X+\ldots \ldots .+\beta k X+U
$$

The Econometric Model,

$$
\mathrm{NER}=\beta 1+\beta 2 \mathrm{INF}+\beta 3 \mathrm{IR}+\beta 4 \mathrm{NFP}+\beta 5 \mathrm{OINT}+\beta 6 \mathrm{TOT}+\beta 7 \mathrm{REM}+\mathrm{U}
$$

Where ' $\mathrm{Y}$ ' is the dependent variable, ie Nominal Exchange Rate. $\beta 1, \beta 2, \beta 3, \beta 4, \beta 5, \beta 6, \beta 7$ are the parameters known as the intercept and slope coefficient in the equation and $U$ is the classical random disturbance term.

The main purpose of the study is to examine the factors that affect exchange rate fluctuations in Sri Lanka, using monthly data for the period 2001 to 2010. Given that some of the variables used in the above models are not directly available, a proxy variable (Net Foreign Purchases) would be used, which will be chosen on the basis of their economic and econometric properties. Secondary data was used from previous research, internal databases of the CBSL, Annual Reports of the Central Bank of Sri Lanka, Monthly Bulletin, recent development trends of the CBSL and other publications of the CBSL.

- Dependent variable - nominal exchange rate

- Independent variables - inflation rate, weighted average call money rate, net official interventions, net foreign purchases, terms of trade and monthly remittances.

To fulfill the specific objectives of the paper, this section tries to identify the main determinants of the exchange rate USD/LKR by utilizing the Multiple Regression Model and VAR techniques. The data is on a monthly basis and covers the period 2001:01-2010:12. All the variables are in logarithms except for the nominal exchange rate, inflation rates and call money rates.

Quite similar to prices of goods and services, exchange rates, being the prices of the currencies, are also determined by demand and supply conditions of the currencies. Any foreign receipts to Sri Lanka, i.e., exports, inward remittances, foreign investments inflow and foreign borrowing, create supply of foreign currencies and demand for Sri Lankan rupees in the foreign exchange market. Any payments to foreign countries, i.e., imports, foreign travel, foreign investments outflow, foreign loan repayments and other payments, involve the purchase (demand for) of foreign currencies and supply of Sri Lankan rupees. In addition, dealings (buying and selling) in foreign currencies seeking financial gain on account of speculation on changes in exchange rates also influence the market demand and supply, and such dealings in globalized foreign exchange markets are key factors in exchange rate volatility. The demand will have an upward pressure on the value of the foreign currency and supply will have a downward pressure. The increase in the value of a currency against another currency, is termed as appreciation of the currency whereas, a decline in the value is the depreciation of the currency. 
The demand for and supply of foreign currencies will change due to various factors relating to the economic activities of the countries. The growth of the national income of a country is a factor that will increase the demand for foreign currencies because the high income will increase the demand for imports. Inflation in a country will increase the demand for foreign currencies due to the tendency to import more, on one hand, and reduce the supply of foreign currencies as a result of the declined demand for exports due to high domestic prices, on the other hand. Expansion in money supply is a factor that will increase the demand for foreign currencies because increased ability to spend due to increased availability of money will raise imports. Therefore, it is believed that exchange rates are determined by demand and supply conditions driven by macroeconomic fundamentals that are linked to transactions in international trade, services and finance.

\section{Ordinary Least Squares (OLS) Method}

In statistics, ordinary least squares (OLS) is a method for estimating the unknown parameters in a linear regression model. This method minimizes the sum of squared vertical distances between the observed responses in the data set and the responses predicted by the linear approximation. The resulting estimator can be expressed by a simple formula, especially in the case of a single regressor on the right-hand side.

The unit root test was used to identify whether time series variables are stationary or nonstationary using an Autoregressive Model through the Augmented Dickey-Fuller (ADF) test. Most of the macroeconomic variables appear to be non-stationary because time series data are highly dependent on the actual time and do not have constant mean and variance (Gujarati 2007). Hence, for non-stationary variables, the unit root test was used in order to avoid the problem of spurious regressions, as follows.

Augmented Dickey Fuller Unit root tests are carried out to test whether the series are level stationary (I (0)) or first difference stationary (I (1)). If the data series is non- stationary, the first difference or first difference with $\log$ value has to be taken. If the mean is not constant, the first difference of the series is taken. Then series can convert to stationary. If the mean and variance both are not constant, lag first difference is taken.

\section{Unrestricted Vector Auto Regression Method.}

The following econometric tool is used in this analysis:

A. Vector Auto Regression-Vector Auto Regression (VAR) model is a system of equation in which each variable is explained by its own lags and current value, and lags of the other variables in the system. The VAR approach also provides an appropriate framework for making sectorial comparisons. The same reduced from equations can be used in all sectors for estimating the response of output to monetary shock. Also, the VAR approach allows the data 
to determine the shape of the impulse responses for different sectors. With the Vector Autoregressive model it is possible to approximate the actual process by arbitrarily choosing lagged variables. Thereby, one can form economic variables into a time series model without an explicit theoretical idea of the dynamic relations. The most easy Multivariate Time Series model is the Bivariate Vector Autoregressive model with two dependent variables ' $y 1, t$ ' and ' $\mathrm{y} 2, \mathrm{t}$ ', where $\mathrm{t}=1, \ldots, \mathrm{T}$. This means, the explanatory variables in the Simplest model are ' $\mathrm{y} 1, \mathrm{t}$ 1' and' y2,t-1'. The VAR (1) with lagged values for each variable is determined by:

$$
\begin{gathered}
\mathrm{y} 1, \mathrm{t}=\alpha 11 \mathrm{y} 1, \mathrm{t}-1+\alpha 12 \mathrm{y} 2, \mathrm{t}-1+\varepsilon 1, \mathrm{t} \\
\mathrm{y} 2, \mathrm{t}=\alpha 21 \mathrm{y} 1, \mathrm{t}-1+\alpha 22 \mathrm{y} 2, \mathrm{t}-1+\varepsilon 2, \mathrm{t} \\
\mathrm{yt} \quad=\mathrm{A} 1 \mathrm{yt}-1+\varepsilon \mathrm{t} \\
(\mathrm{A} 1=\alpha 11 \alpha 12 \\
\alpha 21 \alpha 22)
\end{gathered}
$$

\section{Assumptions about the Error Terms:}

The expected residuals are zero: $\mathrm{E} \quad \mathrm{Ei,t} \quad=0 \quad$ with $\mathrm{i}=1,2$

1. The error terms are not auto correlated:

$$
\mathrm{E} \quad\left[\mathcal{E i}_{\mathrm{i}, \mathrm{t}} . \mathrm{Ej}_{\mathrm{j}} \mathrm{\dagger}\right] \quad=0 \text { with } \mathrm{t} \neq \uparrow
$$

The VAR-model does not allow us to make statements about causal relationships. This holds when the VAR-model is only approximately adjusted to an unknown time series process, while a causal interpretation requires an underlying economic model. However, VAR-models allow interpretations about the dynamic relationship between the indicated variables.

\section{VAR (p)-Models with more than two Variables}

VAR (p)-model, with p variables, is given as:

$$
y t=A 1 y t-1+\text { A2yt }-2+\ldots . .+ \text { Apyt }-p+E t
$$


If one wants to expand the equation with a trend, intercept or seasonal adjustment, it will be necessary to augment the Vector ' $x t$ ', which includes all the deterministic components, and the matrix B (VARX-Model):

$$
\text { yt }=\text { A1yt }-1+\text { A2yt }-2+\ldots . .+ \text { Apyt-p }+ \text { Bxt }+\mathcal{E}
$$

B. Impulse Response - Impulse Response function gives how the other variables react when there is a shock to one variable. The dynamic adjustment of reciprocal dependency is immediately not considerable. The impulse response test shows the effects of an exogenous shock on the whole process over time. Therefore, one can detect the dynamic relationships over time. Initially, look at the adjustment of the endogenous variables over time, after a hypothetical shock in ' $t$ '. This adjustment is compared with the time series process without a shock, i.e, the actual process. The impulse response sequences plot the difference between these two time paths.

C. Variance Decomposition - It is necessary that all the variables in the model are stationary for analysis in terms of variance decomposition. An alternative to impulse response to receive a compact overview of the dynamic structures of a VAR model, is variance decomposition sequences. This method is also based on a Vector Moving Average model and orthogonal error terms. In contrast to impulse response, the task of variance decomposition is to achieve information about the forecast ability. The idea is that even a perfect model involves ambiguity about the realization of ' $y t-1$ ' because the error terms associate uncertainty. According to the interactions between the equations, the uncertainty is transformed to all equations. The aim of the decomposition is to reduce the uncertainty in one equation to the variance of error terms in all equations.

D. AR Root Test - The AR Root test confirms whether the variables used in the analysis are stationary or non- stationary.

\section{Preview of Data}

Aside from factors such as interest rates and inflation, the exchange rate is one of the most important determinants of a country's relative level of economic health. Exchange rates play a vital role in a country's level of trade, which is critical to most free market economies in the world. For this reason, exchange rates are among the most watched, analyzed and governmentally manipulated economic measures. But exchange rates matter on a smaller scale as well, they impact the real return of an investor's portfolio. The major forces behind exchange rate movements are described below. 


\section{- Inflation}

As a general rule, a country with a consistently lower inflation rate exhibits a rising currency value, as its purchasing power increases relative to other currencies. Countries with higher inflation typically see depreciation in their currency in relation to the currencies of their trading partners. A higher rate of inflation leads to the depreciation of a currency vis-a-vis another where inflation is lower. A relationship can be established between appreciation/depreciation and inflation rates. This is also usually accompanied by higher interest rates.

The figure 01 illustrates a weak negative relationship between nominal exchange rate and inflation during the period 2001 to 2010. The correlation coefficient between exchange rate and inflation is $\mathbf{- 0 . 0 3}$.

\section{Figure 01: Nominal Exchange Rate (USD/LKR) and Inflation}

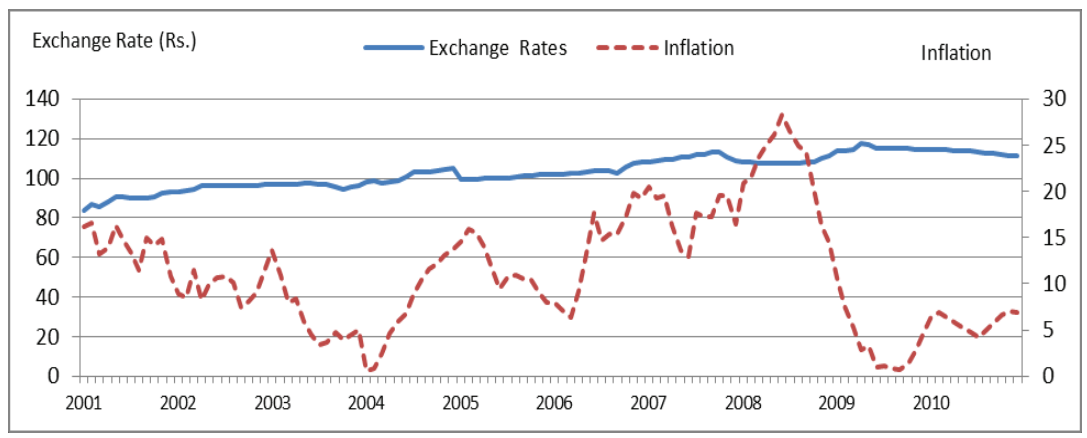

\section{- Interest Rates}

Interest rates, inflation and exchange rates are all highly correlated. By manipulating interest rates, central banks exert influence over both inflation and exchange rates, and changing interest rates impact inflation and currency values. Higher interest rates offer lenders in an economy a higher return relative to other countries. Therefore, higher interest rates attract foreign capital and cause the exchange rate to rise. The impact of higher interest rates is mitigated, however, if the inflation in the country is much higher than in others, or if additional factors serve to drive the currency down. The opposite relationship exists for decreasing interest rates - that is, lower interest rates tend to decrease exchange rates.

The chart (Figure 2) below shows a weak negative relationship between exchange rate and monthly interest rate (call money rates) for 2001 to 2010, due to the correlation between exchange rate and interest rate, being $\mathbf{- 0 . 1 8}$. 
Figure 02: Nominal Exchange Rate (USD/LKR) and Interest Rate

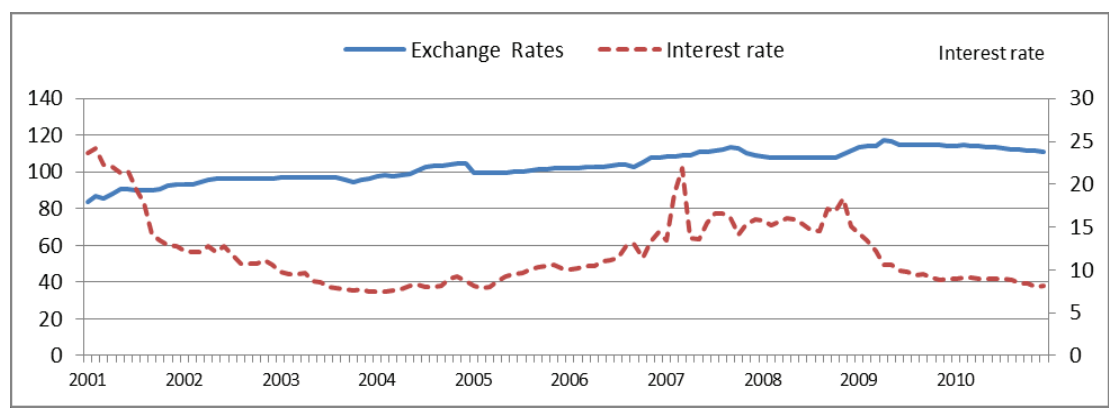

\section{- 'Terms of Trade}

A ratio comparing export prices to import prices, the terms of trade is related to current accounts and the balance of payments. If the price of a country's exports rises by a greater rate than that of its imports, its terms of trade have favorably improved. Increasing terms of trade show a greater demand for the country's exports. This, in turn, results in increasing revenues from exports, which provides an increased demand for the country's currency (and an increase in the currency's value). If the price of exports rises by a smaller rate than that of its imports, the currency's value will decrease in relation to its trading partners.

Figure 03 represents the fluctuations of the nominal exchange rate and terms of trade during the past decade, 2001 to 2010. There is a negative relationship between exchange rate and terms of trade where the correlation is $\mathbf{- 0 . 6 2}$.

Figure 03: Nominal Exchange Rate (USD/LKR) and Terms of Trade (USD Mn)

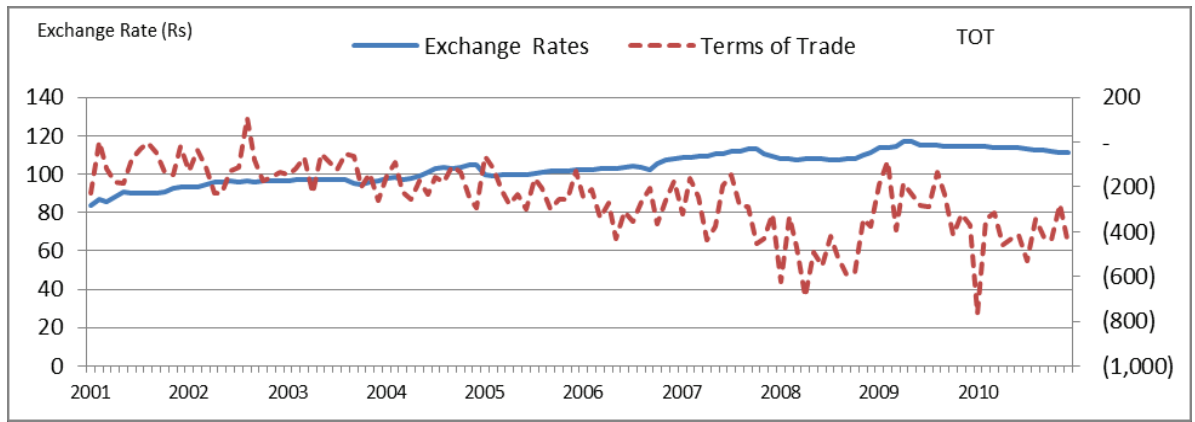




\section{- Net official intervention}

The Central Bank of Sri Lanka intervenes in the market to smoothen the USD/LKR excessive volatility. Though Sri Lanka adopted the free exchange rate system from 2001, practically, the Central Bank always determines the range of the buying and selling band on daily basis. When market forces violate the bands, the Central Bank intervenes to keep the exchange rate at the desired level. On the other hand, it is a signal to the market to follow the desired band, escaping market forces. The principal purpose of official intervention in exchange markets is to reduce short-run exchange rate fluctuations, or "smooth" medium- term movements in exchange rates, through the purchase of foreign exchange when the home currency tends to appreciate and the sale of foreign exchange when the home currency tends to depreciate.

The following chart (Figure 04) shows a positive relationship between the nominal exchange rate (USD/LKR) and official intervention (US Dollar Mn) from 2001 to 2010 and the correlation value is 0.12 .

\section{Figure 04: Nominal Exchange Rate (USD/LKR) and Official Intervention (US} Dollar Mn

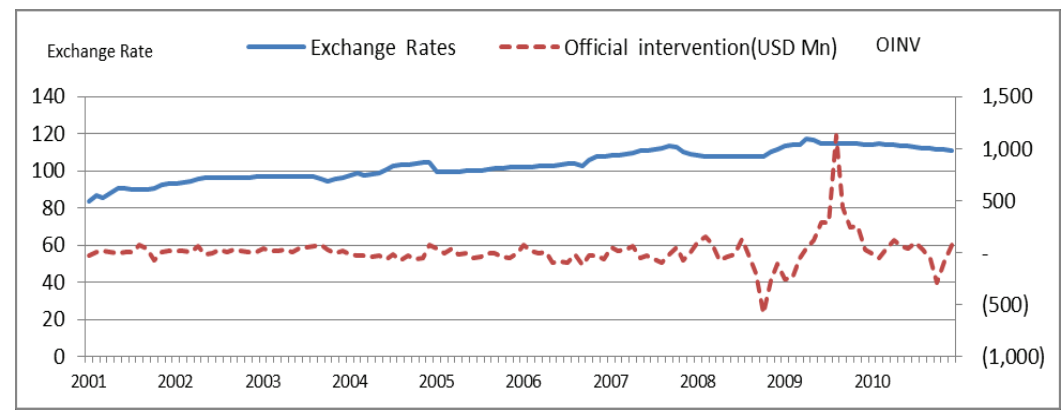

\section{- Remittances}

Remittances are money transfers by migrants to their home countries. In recent years, remittances have played an increasingly significant role in the growth of many developing countries. Workers' remittances have become the second largest source of net financial flows to developing countries. Remittances can affect long-term growth through several channels, one of which is the exchange rate. Changes in the nominal exchange rate affect the distributional impact of remittance inflows, both by altering the returns to factors related to the traded and non-traded goods sectors and by affecting the relative price of traded and nontraded consumption goods. 
It is evident from the graph (Figure 05) below that there is a strong positive relationship between the nominal exchange rate (USD/LKR) and monthly worker remittances (US Dollar Millions) from 2001 to 2010 where the correlation is 0.87 .

\section{Figure 05: Nominal Exchange Rate (USD/LKR) and Monthly Worker Remittances (US Dollar Mn)}

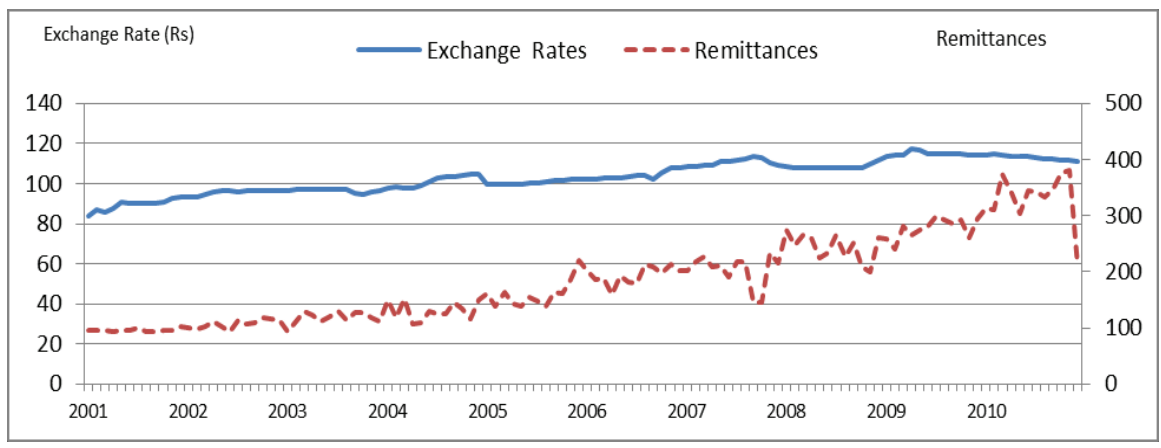

\section{- Net Foreign Purchases}

Net foreign purchases are measured by the difference between sales and purchases of the foreigners. The relationship between net foreign purchases and the nominal exchange rate has long been understood in the theoretical literature. In a simple Keynesian setting, countries with large external liabilities need to run trade surpluses in order to service them, and achieving trade surpluses requires a relatively depreciated currency. In particular, it is recognized that while in the steady state a positive NFP position supports a more appreciated exchange rate, in transition, the exchange rate movements may be a means of reaching a desired level of net foreign Purchases.

The graph (Figure 06) below depicts a weak negative relationship between the nominal exchange rate (USD/LKR) and monthly net foreign purchases (US Dollar Mns) from 2001 to 2010. The correlation between the exchange rate and net foreign purchases is $\mathbf{- 0 . 1 0}$. 
Figure 06: Nominal Exchange Rate (USD/LKR) and Monthly Net Foreign Purchases (US Dollar Mn)

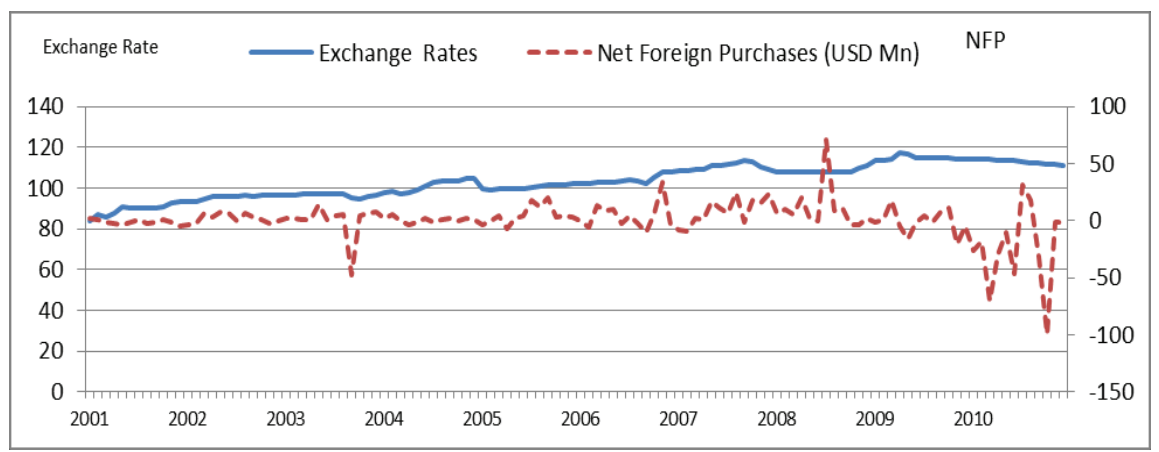

\section{Unit Root Test}

Many macroeconomic data are non- stationary data. Therefore, we have to convert those nonstationary data to stationary data. The unit Root test is carried out to test whether the series are level stationary (I (0)) or first difference stationary (I (1)). The Augmented Dickey Fuller Test was used to check the stationary of variables. There are five variables in DLOG form (Growth rate), namely; exchange rate, inflation, interest rate, remittances and terms of trade. The results of the unit root test for all variables are given in Table 01 below. Results of the Augmented-Dickey Fuller tests confirm that three variables (Exchange Rate, Inflation and Remittances) are non-stationary at the level. The variables became stationary only after taking the first difference.

Table 01: ADF Test Result

\begin{tabular}{ccc}
\hline \hline Variable & Level (P Value) & 1st Difference (P value) \\
\hline ER & 0.3821 & 0.0000 \\
INF & 0.2457 & 0.0000 \\
IR & 0.0551 & $*$ \\
REMI & 0.8030 & 0.0000 \\
OINTV & 0.0000 & $*$ \\
NFP & 0.0000 & $*$ \\
GRTOT & 0.0001 & $*$ \\
\hline
\end{tabular}

* Already significant at Level 
Table 02: Intermediate ADF Test Results

Untitled

\begin{tabular}{ccccc}
\hline \hline Series & Prob. & Lag & $\begin{array}{c}\text { Max } \\
\text { Lag }\end{array}$ & Obs \\
\hline DLOG(ER) & 0.0000 & 0 & 12 & 118 \\
DLOG(INF) & 0.0000 & 0 & 12 & 118 \\
DLOG(IR) & 0.0000 & 1 & 12 & 117 \\
DLOG(REMI) & 0.0000 & 1 & 12 & 117 \\
OINTV & 0.0000 & 0 & 12 & 119 \\
NFP & 0.0000 & 0 & 12 & 119 \\
GRTOT & 0.0000 & 0 & 12 & 118 \\
\hline
\end{tabular}

If the Augmented Dickey - Fuller test statistic value is smaller than the critical values, the null hypotheses of all variables are rejected. Alternatively, the probability value can be used. According to Table 02, the unit root test for all five variables confirm that they are stationary in the level at the 1 per cent level of significance.

\section{Lag selection criteria}

The determination of lag length is a trade-off between the curses of dimensionality and abbreviates models, which are not appropriate to indicate the dynamic adjustment. If the lag length is too short, autocorrelation of the error terms could lead to apparently significant and inefficient estimators. Therefore, one would receive wrong results. On the other hand, with increasing number of parameters, the degrees of freedom decrease, which could possibly result in significant of inefficient estimators.

The idea of information criteria is similar to the trade-off discussed above. On one hand, the model should be able to reflect the observed process as precisely as possible (error terms should be as small as possible) and on the other hand, too many variables lead to inefficient estimators. Therefore, the information criteria are combined out of the squared sum of residuals and a penalty term for the number of lags. In detail, for ' $\mathrm{T}$ ' observations I chose the lag length ' $\mathrm{P}$ ' in a way that the reduction of the squared residuals after augmenting lag ' $\mathrm{P}+1$ ', is smaller than the according boost in the penalty term. Hence, I have selected the 1 st lag based on the AIC (refer Table 03). 
Table 03: Lag selection criteria

Endogenous variables: DLOG(ER) DLOG (INF) DLOG (IR) DLOG (REMI) OINTV NFP GRTOT

Exogenous variables: $\mathrm{C}$

\begin{tabular}{lllllll}
\hline \hline Lag & Log L & LR & FPE & AIC & SC & HQ \\
\hline 0 & -2835.54 & NA & $6.58 \mathrm{e}+13$ & 51.68254 & $51.85439^{*}$ & $51.75224^{*}$ \\
1 & -2778.201 & 106.3375 & $5.66 \mathrm{e}+13 *$ & $51.53092^{*}$ & 52.90571 & 52.08855 \\
2 & -2732.603 & 78.76024 & $6.09 \mathrm{e}+13$ & 51.59278 & 54.17051 & 52.63832 \\
3 & -2704.746 & 44.57023 & $9.18 \mathrm{e}+13$ & 51.97721 & 55.75788 & 53.51067 \\
4 & -2652.731 & $76.60391 *$ & $9.14 \mathrm{e}+13$ & 51.92239 & 56.90600 & 53.94377 \\
5 & -2612.79 & 53.73878 & $1.17 \mathrm{e}+14$ & 52.08710 & 58.27365 & 54.59640 \\
6 & -2566.965 & 55.82345 & $1.42 \mathrm{e}+14$ & 52.14482 & 59.53432 & 55.14204 \\
7 & -2511.004 & 61.04855 & $1.52 \mathrm{e}+14$ & 52.01825 & 60.61069 & 55.50339 \\
8 & -2453.308 & 55.59811 & $1.71 \mathrm{e}+14$ & 51.86014 & 61.65552 & 55.83320
\end{tabular}

* indicates lag order selected by the criterion

LR: sequential modified LR test statistic (each test at 5\% level)

FPE: Final prediction error

AIC: Akaike information criterion

SC: Schwarz information criterion

HQ: Hannan-Quinn information Criterion

\section{Mean root graph}

Further, Auto regressive Roots graph (Figure 07) for Vector Auto Regression model confirms that all the variables used in this analysis are stationary as a system. 
Figure 07: Inverse Roots of AR Characteristic Polynomial

Inverse Roots of AR Characteristic Polynomial

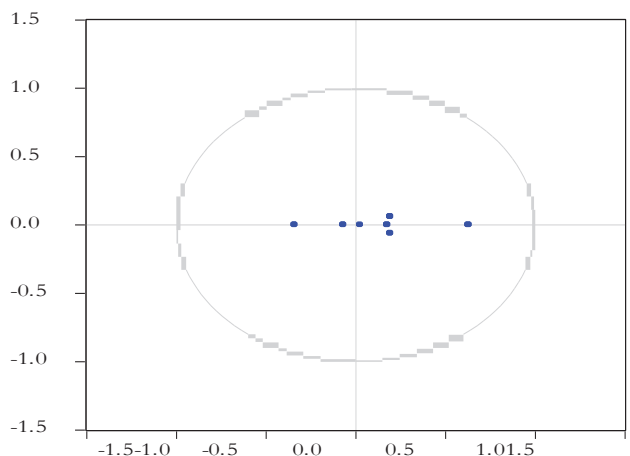

Table 4: Variance Decomposition

\begin{tabular}{lllllllll}
\hline \hline Period & S.E. & $\begin{array}{l}\text { DLOG( } \\
\text { ER) }\end{array}$ & $\begin{array}{l}\text { DLOG } \\
(\mathbf{I N F})\end{array}$ & $\begin{array}{l}\text { DLOG } \\
(\mathbf{I R})\end{array}$ & $\begin{array}{l}\text { DLOG } \\
(\mathbf{R E M I})\end{array}$ & OINTV & NFP & GRTOT \\
\hline 1 & 0.009541 & 100.0000 & 0.000000 & 0.000000 & 0.000000 & 0.000000 & 0.000000 & 0.000000 \\
2 & 0.009991 & 95.70883 & 0.230313 & 0.310263 & 0.482713 & 2.342029 & 0.279075 & 0.646782 \\
3 & 0.010102 & 93.81899 & 0.289129 & 0.306257 & 0.496123 & 4.035239 & 0.399681 & 0.654577 \\
4 & 0.010148 & 93.01329 & 0.287160 & 0.305514 & 0.494788 & 4.818153 & 0.430207 & 0.650884 \\
5 & 0.010166 & 92.67542 & 0.287292 & 0.310291 & 0.493369 & 5.140369 & 0.444248 & 0.649008 \\
6 & 0.010174 & 92.53962 & 0.288162 & 0.312393 & 0.492668 & 5.268898 & 0.450018 & 0.648236 \\
7 & 0.010177 & 92.48544 & 0.288465 & 0.313439 & 0.492381 & 5.319813 & 0.452537 & 0.647927 \\
8 & 0.010178 & 92.46397 & 0.288610 & 0.313836 & 0.492265 & 5.339961 & 0.453552 & 0.647804 \\
9 & 0.010179 & 92.45546 & 0.288662 & 0.313999 & 0.492219 & 5.347937 & 0.453964 & 0.647756 \\
10 & 0.010179 & 92.45209 & 0.288684 & 0.314063 & 0.492201 & 5.351095 & 0.454127 & 0.647736 \\
\hline
\end{tabular}

It is necessary that all the variables in the model are stationary for analysis in terms of variance decomposition. Variance decomposition of the growth in the exchange rate (DLOGER) gives the changes in the variable DLOGER attributable to each of the other variables.

The results of the variance decomposition with respect to DLOGER are given in Table 4 (Variance decomposition). The variance decomposition of the exchange rate gives the changes in the growth in ER, attributable to each of the other variables included in the model, as well as itself.

Within this period (120 Months), about 0.45 of the variance in the growth in ER is from net foreign purchases, about 0.30 of the variance is from the growth in the inflation, about 0.31 
of the variance is from the monthly increase in the weighted average call money rate, while about 0.45 of the variance is from the growth of net official interventions and about 0.49 of the variance is from monthly remittances, whereas 0.65 of the variance is from the terms of trade.

Figure 08: Impulse Response Function

\section{Response to Cholesky One S.D. Innovations}
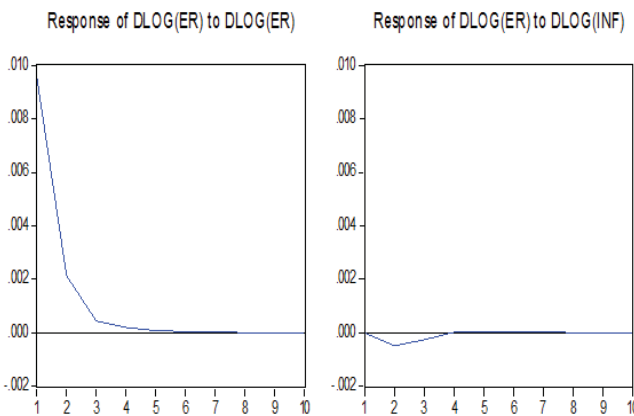

Response of DLOG(ER) to DLOG(R)

Response of DLOG(ER) to DLOG(REMI)

Response of DLOG(ER) to OINTV
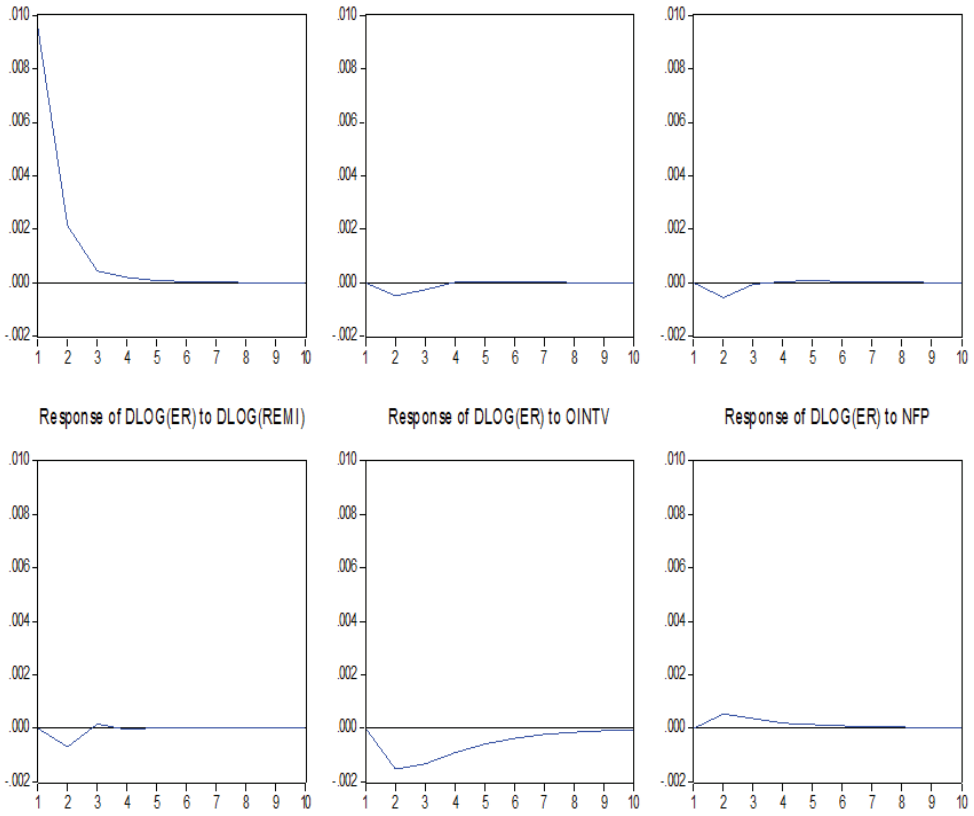

Response of DLOG(ER) to NFP

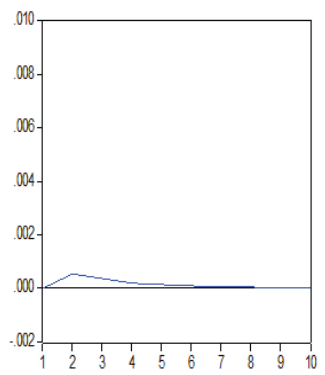

Response of DLOG(ER) to GRTOT

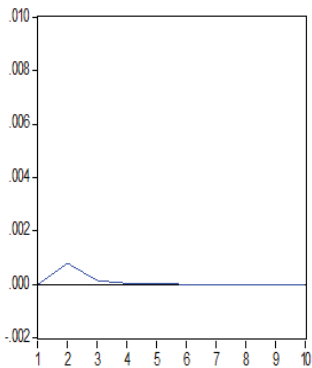


The impulse response function indicates the effect of a one standard deviation shock to one of the innovations on current and future values of the endogenous variables. The results of impulse response functions (except response of NER to NER) are given in Figure 08 (Impulse response function) which shows that an increase in the official interventions has a negative impact on the nominal exchange rate. On the other hand, an increase in interbank call money market rates has some impact to the nominal exchange rate from 1 to 3 months and persists 3 to 6 months after it dies. The response of inflation rate to exchange rate has a negative impact during the first 4 months, thereafter it dies out. We can see a positive response of net foreign purchases to exchange rate from 1 to 6 and afterwards it dies out. The response of terms of trade has a positive impact to the exchange rate from 1 to 3 months, subsequently it dies out. On the other hand, the response of monthly remittances has a negative effect from 1 to 3 months, is slightly positive during 3 to 4 months and thereafter dies out.

According to the estimation results of Vector Auto Regression, net official intervention, net foreign purchases and call money rate affect the fluctuations of the exchange rate. However, when compared to the pass-through process of inflation rate to exchange rate, it is not very significant.

\section{7. $\quad$ Results}

This section explains the empirical findings with regard to factors that determine the exchange rate. Firstly, a brief explanation with regard to descriptive statistics is mentioned below. Secondly, I have estimated the Multiple Regression Model and discussed the correlation between the exchange rate and other independent variables, as well as its coefficients. Finally, results are discussed by means of impulse response functions of a VAR Model.

Table 05: Results of Descriptive Statistics

\begin{tabular}{llllllll}
\hline \hline & ER & INF & IR & NFP & OINTV & REMI & TOT \\
\hline Mean & $\mathbf{1 0 3 . 4 1 6 2}$ & $\mathbf{1 1 . 2 7 2 2 8}$ & $\mathbf{1 1 . 9 2 4 2 0}$ & $\mathbf{0 . 5 0 0 0 0 0}$ & $\mathbf{6 . 7 4 4 3 0 5}$ & $\mathbf{1 8 5 . 9 5 4 6}$ & $\mathbf{- 2 5 2 . 1 1 4 5}$ \\
Median & 102.8732 & 10.75624 & 10.59000 & 2.000000 & 0.000000 & 163.5683 & -233.4756 \\
Maximum & 117.3699 & 28.23584 & 24.23000 & 90.00000 & 1130.750 & 381.4847 & 110.2653 \\
Minimum & 83.66220 & 0.517117 & 7.470000 & -479 & -587.7 & 92.65000 & -765.9135 \\
Std. Dev. & $\mathbf{8 . 0 8 6 1 2 1}$ & $\mathbf{6 . 3 9 4 4 4 4}$ & $\mathbf{3 . 9 6 1 9 3 3}$ & $\mathbf{5 3 . 9 7 5 5 6}$ & $\mathbf{1 5 1 . 6 3 5 9}$ & $\mathbf{7 8 . 0 1 6 9 5}$ & $\mathbf{1 5 5 . 6 9 2 4}$ \\
Skewness & -0.177604 & 0.456558 & 1.168569 & -6.150496 & 3.084103 & 0.657211 & -0.672948 \\
Kurtosis & 2.083628 & 2.657085 & 3.805913 & 54.32179 & 28.87417 & 2.427789 & 3.482043 \\
Jarque-Bera & $\mathbf{4 . 8 2 9 5 4 7}$ & $\mathbf{4 . 7 5 6 8 5 4}$ & $\mathbf{3 0 . 5 5 8 5 3}$ & $\mathbf{1 3 9 2 6 . 2 0}$ & $\mathbf{3 5 3 7 . 5 9 6}$ & $\mathbf{1 0 . 2 7 5 6 6}$ & $\mathbf{1 0 . 2 1 9 0 0}$ \\
Probability & 0.089388 & 0.092696 & 0.000000 & 0.000000 & 0.000000 & 0.005870 & 0.006039 \\
Sum & 12409.94 & 1352.674 & 1430.904 & 60.00000 & 809.3165 & 22314.55 & -30253.74 \\
Sum Sq. Dev. & 7780.858 & 4865.780 & 1867.933 & 346690.0 & 2736220. & 724310.8 & 2884574. \\
Observations & 120 & 120 & 120 & 120 & 120 & 120 & 120 \\
\hline
\end{tabular}


Table 05 depicts the average nominal exchange rate to be 103.4162, the average inflation rate is around 11.27 per cent and interest rate to be 11.92 per cent. A higher volatility can be observed in official intervention and terms of trade. According to the Jarque - Bera values, this data distribution is not a normal distribution.

The data analysis method used in this paper is to identify the determinants of the exchange rate. The results were estimated using the Vector Auto Regression (VAR) method.

Multiple Regression Results: Dependent Variables NER

Table 06: OLS Results of Multiple Regression Model

\begin{tabular}{|c|c|c|c|c|c|}
\hline Variable & Coefficient & Std. Error & & t-Statistic & Prob. \\
\hline C & 0.002534 & & 0.000909 & 2.789256 & 0.0062 \\
\hline DLOG(INF) & -0.002654 & & 0.002713 & -0.977981 & 0.3302 \\
\hline DLOG(IR) & -0.000745 & & 0.011377 & -0.065493 & 0.9479 \\
\hline DLOG(REMI) & -0.013351 & & 0.007269 & -1.836642 & 0.0689 \\
\hline OINTV & $-1.11 \mathrm{E}-05$ & & $5.97 \mathrm{E}-06$ & -1.853063 & 0.0665 \\
\hline NFP & 6.31E-11 & & $5.14 \mathrm{E}-11$ & 1.228412 & 0.2219 \\
\hline GRTOT & $-7.68 \mathrm{E}-06$ & & $1.95 \mathrm{E}-06$ & -3.944056 & 0.0001 \\
\hline R-squared & 0.179901 & Mean dependent var & & & 0.002440 \\
\hline Adjusted R-squared & 0.135572 & S.D. dependent var & & & 0.010478 \\
\hline S.E. of regression & 0.009742 & Akaike info criterion & & & -6.367348 \\
\hline Sum squared resid & 0.010534 & Schwarz criterion & & & -6.202985 \\
\hline Log likelihood & 382.6735 & Hannan-Quinn criter. & & & -6.300611 \\
\hline F-statistic & 4.05826 & Durbin-Watson stat & & & 1.591854 \\
\hline Prob(F-statistic) & 0.001023 & & & & \\
\hline
\end{tabular}

The empirical studies by Fry (1976), Bilson (1978), Messe and Rogoff (1983), Sebastian (1983), Woo (1985), and Oloyede (1997), to mention a few, have shown that the CAM model can be used to explain the stylized facts of the behavior of the inflation rate and the nominal exchange rate in many small open economies. For example, countries with relatively high rates of 
monetary growth are expected to have high rates of inflation and depreciating exchange rates. However, using the OLS model, I found that my result shows a negative relationship between the exchange rate and inflation as the coefficient is negative, when inflation increases by 1 per cent rupee appreciates by 0.002 per cent. This may be due to the effects of some high volatile periods of inflation. However, the estimated coefficient is statistically insignificant.

According to my output, when inflation increases call money rates will also increase; as a result, exchange rate will appreciate. When interest rate increases by 1 per cent, exchange rate will appreciate by 0.0007 per cent. Hence the results indicate a negative relationship between call money rates and the nominal exchange rates. This can be empirically supported by Bjrnland (2009) who identifies a similar relationship to our research by imposing a long-run neutrality restriction on the exchange rate, thereby allowing for contemporaneous interaction between the interest rate and the exchange rate. In particular, a contractionary monetary policy shock has a strong effect on the exchange rate, which appreciates on impact.

If worker remittances increase, exchange rate should appreciate. Therefore, I have found a negative relationship between exchange rate and remittances: 1 per cent in remittances leads to appreciation of the exchange rate on 0.01 per cent. In contrast, Lin's (2001) paper analyzes the determinants of remittances to Tonga. The results indicate that macroeconomic conditions in remitting countries and exchange rate fluctuations influence remittances. In particular, remittances growth falls when the Tongan currency appreciates, but increases with higher real GDP growth and lower unemployment in remitting countries. The analysis also found that the influence of these determinants varies with the recipients of remittances, with remittances to non-profit organizations being more sensitive to an appreciation of the Tongan currency.

As per my results, there is a negative relationship between exchange rates and net official interventions because when the Central Bank injects dollars to the market, the rupee will appreciate against the dollar. Behera et al.'s (2000) paper empirically explores the relationship between central bank intervention and exchange rate behavior in the Indian foreign exchange market. Specifically, the paper investigates the effects of RBI intervention on exchange rate level and volatility. The results using the GARCH model confirms that the intervention of RBI is effective in reducing volatility in the Indian foreign exchange market. Canales et.'s(2003) paper in contrast, offers guidance on the operational aspects of official intervention in the foreign exchange market, particularly in developing countries with flexible exchange rate regimes. The analysis highlights the difficulty of detecting exchange rate misalignments and disorderly markets, and argues in favor of parsimony in official intervention.

According to the analytical result, there is a positive relationship between net foreign purchases and the exchange rates. When net foreign purchases decrease (net sales increase) it will lead to an outflow of more Dollars from the country. Therefore, nominal exchange rate will appreciate. Thus, my result can be empirically supported by Peng et al.'s (2003) paper, which 
assesses the equilibrium value of the yen within a VECM framework by considering a number of fundamental factors, in particular net foreign purchases holdings. Based on an established co integrating relationship between the exchange rate and economic fundamentals, the trend value of the Yen is estimated to have remained broadly stable since the early 1990s. The continuous accumulation of net foreign purchase has underpinned the strength of the yen, as its positive impact offset the downward pressure arising from the deterioration of the terms of trade and slower relative productivity growth.

There is a negative relationship between exchange rate and terms of trade. When our terms of trade worsens, the exchange rate will depreciate. Wimalasuriya's (2007) findings from the model suggest that changes in the exchange rate could have significant implications for the trade balance. More precisely, the most important variable affecting the exchange rate equilibrium level is the terms of trade. Although, Drine et al. (2003) show that an improvement in terms of trade entails a long-run appreciation of the exchange rate. On the other hand, an increase of domestic investment and degree of openness the economy entails an exchange rate depreciation; the effect of public spending increase being ambiguous.

\section{Concluding Remarks}

This paper examines the factors that affect exchange rate fluctuations in Sri Lanka. According to the empirical results, there is a positive relationship between net foreign purchases and the exchange rate. This study finds that the terms of trade is a determinant of the nominal exchange rate in Sri Lanka. A negative relationship exists between the exchange rate and terms of trade. There is a negative relationship between exchange rate and inflation because the coefficient is negative, when inflation increases, the exchange rate will appreciate against the dollar. In addition, there is a link between inflation and call money rates whereas when inflation increases call money rates will also increase, as a result the rupee will appreciate against the dollar. Therefore, there is a negative relationship between call money rates and the nominal exchange rates. If worker remittances increase the exchange rate should appreciate. Therefore, the results show a negative relationship between exchange rate and remittances. Most variables have a significant impact on exchange rate, peak effect within a two month lag. The DurbinWatson Statistic was found to be 1.60, suggesting that the model specification was somewhat appropriate; this means that relevant variables have been included.

However, the size of the coefficient that relates monetary policy to the exchange rate was found to be relatively small. This points out the need for further research to analyse the impact of determinants on the exchange rate.

On the other hand, this study has several limitations, some of which are related to data availability. One such limitation is that proper net capital inflows do not exist for the entire sample period. Hence, I tend to use a proxy variable (Net Foreign Purchases) instead of Net 
Capital Inflows, as there is no monthly data available for capital inflows. Further in this paper, I have considered only six dependent variables even though there are many influential factors that determine the exchange rate. One other limitation is the control over the capital account of Sri Lanka. The REPO market, initiated in 1996, and foreign participants involvement was limited to five per cent of total securities issued, though currently it has expanded to ten per cent. Therefore, the relationship between the exchange rate and interest rate cannot be implemented freely because of capital controls. Further this ten per cent foreign participant involvement limit was introduced in October 2010, hence the impact from this limit change will not be effectively shown in our results due to the time period constraint, i.e., using data from 2001: 01 January -2010: 12 December.

Moreover, in this paper more emphasis is placed on determinants of nominal exchange rate under the managed floating exchange rate regime. However, it can be extended to account for the effects of real exchange rate shocks and costs of exchange rate fluctuations with regard to the exchange rate determinants. Furthermore, it compels us to explore future work as to whether there is any economic value to the predictive power of economic fundamentals for nominal exchange rates. Overall, more research may be needed to identify the determinants of real exchange rate. 


\section{References}

Alawattage, U P. "Exchange Rate, Competitiveness and Balance of Payment

Performance." Staff Studies, Vol. 34, No. 1, Central Bank of Sri Lanka, 2005,pp.1-29.

Wijeweera, Albert and Brian, Dollery. "An econometric analysis of Sri Lankan monetary policy shocks and exchange rates." Global Business and Economics Review, Vol. 10, No. 1, 2008, pp. 58-67.

Atish, R. Ghosh Jonathan, D. Ostry Anne-Marie Gulde - Holger C. Wolf. "Does the Exchange Rate Regime Matter for Inflation and Growth?" International Monetary Fund, 1996.

Bayoumi, T. and Eichengreen, B. "Exchange Rate Volatility and Intervention: Implications of the Theory of Optimum Currency Areas.” (Second Revision), August 1997.

Behera, H K V. and Narasimhan, K N. Murty "Relationship between exchange rate volatility and central bank intervention: An empirical analysis for India." 2000.

Bilson, J.F.O. "The monetary approach to the exchange rate: Some empirical evidence. "IMF Staff Papers, vol. 25, March, 1978, pp.91-95.

Bilson, J.F.O. and Marston, R.C. "Exchange Rate Theory and Practice." University of Chicago Press, 1984. http://www.nber.org/books/bils84-1.

Dornbusch, Hilde C. "Bjfrnland Monetary policy and exchange rate overshooting." Journal of International Economics, 2009, pp197-221.

Drine, I. and Rault, C. "on the long-run determinants of real exchange rates for developing countries: Evidence from Africa, Latin America and Asia." William Davidson Working Paper Number 571, May 2003.

Edwards, Sebastian. "Real Exchange Rates, Devaluation, and Adjustment, Cambridge, Massachusetts: MIT Press." 1989, pp11-371.

Edwards, S. "Economic Policy and the Dynamics of Growth." Studios de Economic, 1996, pp.137-155.

Edwards, S. and Magendzo, I. “A Currency of One’s Own? An Empirical Investigation on Dollarization and Independent Currency Unions. "NBER Working Paper, 9514, 2003, pp.1-47.

Edwards, S. and Levy-Yeyati, E. "Flexible Exchange Rates as Shock Absorbers." NBER Working paper series, 9867, 2003, pp.1-30.

Evans, Martin D. and Richard, K. Lyons. "Order Flow and Exchange Rate Dynamics." Journal of Political Economy, 102, 2002, pp. 170-180.

Ezirim, C. B. and Muoghalu, M. I. "Exchange Rate Determination, Foreign Investment Burden and External Debt Crisis in Less-Developed Countries: Nigerian Experience." International Journal of Business and Economics Perspectives, Vol. 1, No. 1, 2006.

Fan, Mintao and Richard, K. Lyons. "Customer Trades and Extreme Events in Foreign Exchange." in Essays in Honor of Charles Goodhart, Paul Mizen (ed.), 2003.

Ferdinand, C. Nwafor." the Naira-Dollar Exchange Rate Determination: A Monetary Perspective." School of Business \& Industry Florida A\&M University, 2005.

Francisco Nadal and De Simone and Razzak, W A. "nominal exchange rates and interest rate differentials. "IMF working paper, 1999.

Fry, M. J. “A monetary approach to Afghanistan's flexible exchange rate.” 
Journal of Money, Credit and Banking, vol. 8: 1976, pp.219-225.

Ghosh, Amit and Rajan, Ramkishen, S. "how high are exchange rate pass- through in India? Has it changed over time?" The Journal of International Trade \& Economic Development, 16:3, 2007, pp.373 - 382.

Goldfajn, I and Olivares, G. "Can flexible exchange rates still 'work' in financially open economies?”, G-24 Discussion Paper no 8, United Nations,2001.

Goldfajn, I and Werlang S R C. "The pass-through from depreciation to inflation: a panel study." Textos para discussão no 423, Department of Economics PUCRio, Brazil, 2000.

Hakkio C.S. "Interest rate and Exchange rates-What is the relationship, Economic Review", November 1986, pp.33-43.

Hannah Huidan Lin," Determinants of Remittances: Evidence from Tonga." IMF Working Paper, 2011, pp.1-17.

Harvey, J. T. "Exchange Rate Theory and the Fundamentals." Department of Economics, Taxas Christian University, USA, 2000.

Harischandra, P.K.G. "Monetary Policy and Inflation Performance: Evidence from Exchange Rate Regimes in Sri Lanka." Staff Studies, Volume 37 Numbers 1 and 2, 2007, pp.1-49.

Ito, T. \& Krueger, A.O. "Changes in Exchange Rates in Rapidly Development

Countries: Theory, Practice, and Policy Issues.’University of Chicago Press. 1999, http://www.nber.org/books/ito_99-1.

Jocelyn Horne, eight conjectures about exchange rates. "Journal of Economic

Studies." Vol. 31 No. 6, 2004, pp. 524-548. www.emeraldinsight.com/01443585.htm

Jorge Ivan Canales, Kriljenko, Roberto Guimaraes, and Cem karacadag. "Official Intervention in the Foreign Exchange market. Elements of best practice.” IMF working paper, 2003.

José De Gregorio and Andrea Tokman, R. "Flexible exchange rate regime and forex intervention." 2005.

Kriljenko, J.C. and Habermeier K. "Structural Factors Affecting Exchange Rate Volatility: A Cross-Section Study.” IMF Working Paper-Monetary and Financial Systems Department, 2004.

Lane, P.R. "The new open economy macroeconomics: a survey. Journal of International Economics.” 54, 2001, pp.235-264.

Magda Kandil," The Asymmetric effects of exchange rate fluctuations, Theory and evidences from developing countries." IMF working paper, 2000.

Messe, R. and K. Rogoff. "Empirical exchange rate models of the seventies: Do

they fit out of sample?" Journal of International Economics, vol. 4: 3-24. 1983.

Mohsen Bahmani-Oskooee, Scott W. Hegerty. "Exchange rate volatility and trade flows: a review article." Journal of Economic Studies, Vol. 34 Iss: 3, 2007, pp.211 -255 .

Muhammad Zakaria, Seta Ahmad and M Mazhar Iqbal. "Nominal exchange rate Variability: A case study of Pakistan. "Journal of economic cooperation 28, 1, 2007, pp.73-86. 
Nelson, C. Mark, Donggyu Sul. "Nominal exchange rates and monetary fundamentals: Evidence from a small post-Bretton woods panel." Journal of International Economics, 53, 2001, pp. 29-52.

Noer Azam Achsani, "The Relationship between Inflation and Real Exchange Rate: Comparative Study between ASEAN+3, the EU and North America." Department of Economics and International Centre for Applied Finance and Economics, 2010.

Obstfeld, M. Rogoff, K. "Exchange rate dynamics redox.”, Journal of Political Economy, 91, 2000, pp. 675 - 687.

Oloyede, J.A. "Current account monetary model and exchange rate behavior in LDCs: Evidence from Nigeria, Ghana and Gambia." African Journal of Economic, Policy, vol. 4(2), 1997, pp. 47-65.

Oskooee, M.B. and Hegerty, S.W. "Exchange rate volatility and trade flows: a review article.", Journal of Economic Studies, Vol. 34 No. 3, 2007, pp. 211 255. www.emeraldinsight.com/0144-3585.htm.

Rogoff, K. "On the Effects of Sterilized Intervention: An Analysis of Weekly Data.” Journal of Monetary Economic, Vol. 14, 1984, pp.133-150.

Sebastian, E. "Floating exchange rates in less developed countries". Journal of Money, Credit and Banking, vol. 15(1), 1983, pp.186-204.

Vijay, K. Bhasin. "Department of Economics University of Cape Coast Cape Coast, Ghana, Dynamic inter-links among the exchange rate, price level and terms of trade in a managed floating exchange rate system: The case of Ghana." AERC Research Paper 141 African Economic Research Consortium, Nairobi, and July 2004.

Villavicencio, A.L. and Bara, and J.L.R. "the short and long-run determinants of the real exchange rate in Mexico." Department d'Economia Aplicada-Universitat Aut'onoma de Barcelona, Spain, 2006.

Wensheng Peng, Chang Shu and Kevin Chow. "The Yen Exchange Rate and Net Foreign Assets.” Research Department Hong Kong Monetary Authority, 2003.

Wijesinghe, D.S. "The Equilibrium Real Exchange Rate: The case of Sri Lanka." Staff Studies, Vol 24. No: 01, Central Bank of Sri Lanka, 1999.

Wimalasuriya, S.M. "Exchange Rate Pass-through: To what extend do price change on Sri Lanka?" Staff Studies, Vol. 37, No. 1 \& 2, Central Bank of Sri Lanka, 2007.pp.1-19.

Woo, W.T. "The monetary approach to exchange rate determination under rational expectations: The Dollar-Deutschemark rate". Journal of International Economics, vol. 18: 1985, pp.1-16.

Xiangming Fang October. "A Reappraisal of the Exchange Rate Determination: A Liquidity Approach.” International Business Research Vol. 3, No. 4, 2010.

Yin-Wong Cheung, Menzie, D. Chinn, Antonio Garcia Pascual. "Empirical exchange rate models of the nineties: Are any fit to survive?", Journal of International Money and Finance 24, 2005. 


\section{Appendix 01}

\section{Main Variables}

The main variables considered in this analysis are given below. The analysis consists of mainly six variables. All monthly variables are from the period of 2001 to 2010.

\begin{tabular}{ll}
\hline \hline Variable & Description \\
\hline NEXRATE & Nominal Exchange Rate (USD/LKR) \\
& Central Bank Annual Reports \\
CCPI & Colombo Consumer Price Index \\
& Consumer and Statistics Department \\
NFP & Net Foreign Purchases (US Dollar Million) \\
& Colombo Stock Exchange Monthly Reports \\
REM & Remittances (US Dollar Million) \\
& Central Bank Monthly Bulletins \\
INTCALLMMRATE & Average Inter- bank call money market rate \\
& Central Bank Annual Reports \\
NEOINTERVENTION & Net Official Intervention (USD Million) \\
& Central Bank Annual Reports \\
\hline
\end{tabular}


Appendix 02

\section{Unit root test}

\section{Individual variable unit root test}

Null Hypothesis: Unit root (individual unit root process)

Series: DLOG(ER), DLOG (INF), DLOG (IR), DLOG (REMI), OINTV, NFP,

\begin{tabular}{lcc}
\hline \hline Method & Statistic & Prob.** \\
\hline ADF - Fisher Chi-square & 390.939 & 0.0000 \\
ADF - Choi Z-stat & -18.4395 & 0.0000 \\
& & \\
\hline
\end{tabular}

** Probabilities for Fisher tests are computed using an asymptotic Chi -square distribution. All other tests assume asymptotic normality 
Appendix 03

\begin{tabular}{clc}
\hline \hline Correlation & \multicolumn{1}{c}{ Coefficients } & Correlation \\
\hline Exchange rate & Inflation Rate & -0.03 \\
Exchange rate & Interest Rate & -0.18 \\
Exchange rate & Net Foreign Purchases & -0.10 \\
Exchange rate & Remittances & 0.87 \\
Exchange rate & Net Official Intervention & 0.12 \\
Exchange rate & Terms of Trade & -0.62 \\
\hline
\end{tabular}

